\title{
Projected economic losses due to vector and vector-borne parasitic diseases in livestock of India and its significance in implementing the concept of integrated practices for vector management
}

\author{
B. W. Narladkar \\ Department of Veterinary Parasitology, College of Veterinary and Animal Sciences, MAFSU, Parbhani - 431402 , \\ Maharashtra, India. \\ Corresponding author: B. W. Narladkar, e-mail: babanar47@gmail.com \\ Received: 20-10-2017, Accepted: 21-12-2017, Published online: 09-02-2018
}

doi: 10.14202/vetworld.2018.151-160 How to cite this article: Narladkar BW (2018) Projected economic losses due to vector and vector-borne parasitic diseases in livestock of India and its significance in implementing the concept of integrated practices for vector management, Veterinary World, 11(2): 151-160.

\begin{abstract}
Broadly, species of arthropods infesting livestock are grouped into flies (biting and non-biting), fleas, lice (biting and sucking), ticks (soft and hard), and mites (burrowing, non-burrowing, and follicular). Among which, biting and non-biting flies and ticks are the potent vectors for many bacterial, viral, rickettsial, and protozoan diseases. Vectors of livestock are having economic significance on three points (1) direct losses from their bite and annoyance, worries, and psychological disturbances produced during the act of biting and feeding, (2) diseases they transmit, and (3) expenditure incurred for their control. Flies such as Culicoides spp. and Musca spp. and various species of hard ticks play important role in disease transmission in addition to their direct effects. For control of vectors, recent concept of integrated pest management (IPM) provides the best solution and also addresses the problems related to acaricide resistance and environmental protection from hazardous chemicals. However, to successfully implement the concept of IPM, for each vector species, estimation of two monitory benchmarks, i.e., economic injury level (EIL) and economic threshold level (ETL) is essential prerequisite. For many vector species and under several circumstances, estimation of EIL and ETL appears to be difficult. Under such scenario, although may not be exact, an approximate estimate can be accrued by taking into account several criteria such as percent prevalence of vectors in a geographical area, percent losses produced, total livestock population, and current prices of livestock products such as milk, meat, and wool. Method for approximate estimation is first time described and elaborated in the present review article.
\end{abstract}

Keywords: economic injury levels, economic threshold levels, integrated pest management, vectors.

\section{Introduction}

One of the greatest challenges of the $21^{\text {st }}$ century is the need to feed a growing population while improving the productive capacity of agricultural ecosystems and the health and integrity of surrounding environments for future generations [1]. For enhancing the crop production, indiscriminate use of hazardous chemicals and fertilizers leads to irreparable damage to the health of human, livestock, soil, and environment. In the recent decades, scientists across the globe alarmed about the consequences of this issue. Thus, to address this, enormous research has been done throughout the world, which emerged into a concept of integrated pest management (IPM) and organic production methods, which can work together to address this vital challenge. The integration of livestock into cropping, through draught power and manure, increases the area cultivated, improves the timeliness of agricultural operations, and helps to maintain soil structure and fertility [2], for this purpose, livestock rearing becomes

Copyright: Narladkar. Open Access. This article is distributed under the terms of the Creative Commons Attribution 4.0 International License (http://creativecommons.org/licenses/by/4.0/), which permits unrestricted use, distribution, and reproduction in any medium, provided you give appropriate credit to the original author(s) and the source, provide a link to the Creative Commons license, and indicate if changes were made. The Creative Commons Public Domain Dedication waiver (http://creativecommons.org/ publicdomain/zero/1.0/) applies to the data made available in this article, unless otherwise stated. the complementary and supplementary business to agriculture. Therefore, it is equally true that IPM practices are also necessary to achieve control of ectoparasites involving pests-cum-vectors for livestock.

To achieve the goal of optimum or maximum production from livestock, it is mandatory to increase the number of healthy livestock by scrupulously following good managemental practices, provision of balanced diet, and protection from infectious diseases. In addition to bacterial and viral diseases, protection from vectors and vector-borne diseases is an obligatory step and for which implementation of effective IPM practices is need of the hour. More recently, researches in the areas of various aspects such as physical and biological aspects of control of vector pests had taken a great momentum and are in full swing. By integrating all such aspects of control, there is strong need to develop an IPM module, for which, estimation of two monetary benchmarks, i.e. economic injury level (EIL) and economic threshold level (ETL) is not only prerequisite but also essential step [3]. These two benchmarks suggest the balance between losses accrued on the account of vectors and vector-borne diseases and expenditure incurred on vector control. However, many a time, assessment of exact estimation of EIL and ETL is not possible in a particular geographic area, if the exact estimation of EIL and ETL is not possible, the method proposed in 
the present review article for approximate calculation of economic losses can play a role of pathfinder and thus gains importance.

The present review article is highlighting the importance of IPM for vector-cum-pests of livestock and an alternative approach for approximate estimation of economic losses, by taking into account, epidemiological data in a particular geographic location and losses due to vectors.

\section{Vectors Infecting to Livestock}

Broadly, species of arthropods infesting livestock are grouped into flies (biting and non-biting), fleas, lice (biting and sucking), ticks (soft and hard), and mites (burrowing, non-burrowing, and follicular). Among five major groups of ectoparasites, biting and non-biting flies and ticks are the potent vectors for many bacterial, viral, rickettsial, and protozoan diseases.

\section{What is the Concept of IPM?}

Consequent to effects of global warming, resistance accrued to insecticides on their indiscriminate use, wrong animal husbandry practices and poor status of nutrition, and one or the other reasons, in the past few decades, prevalence of vectors-cum-pests and vector-borne diseases is on high rising trend. The World Health Organization declared on April $7^{\text {th }}, 2014$ on the occasion of world health day, the theme of the year as "Protect yourself from vector-borne diseases." In conclusion, it is need of the hour to combat the vectors and protect our animals from vectors. The best way for combating the vectors is the implementation of IPM or integrated vector management practices suitable to local conditions.

Baker et al. [1] in his book narrated that both organic and IPM tactics require greater management skill to implement effectively than the calendar-based application of inputs. They also cited the definition of IPM given by USDA [4], which gives the impression about each aspect of IPM. According to USDA, IPM is "a science-based, decision-making process that identifies and reduces risks from pests and pest management related strategies. The IPM coordinates the use of pest biology, environmental information, and available technology to prevent unacceptable levels of pest damage by the most economical means while minimizing risk to people, property, resources, and the environment. IPM provides an effective strategy for managing pests in all arenas from developed agricultural, residential, and public lands to natural and wilderness areas. The IPM provides an effective, all encompassing, low-risk approach to protect resources and people from pests." Thus, application of IPM is need of hour to avoid the health and environment related risks strongly posed by present strategies for pest control.

\section{Why IPM is Must?}

\section{Advantages of IPM} et al. [1]. a. "Reduces reliance on single tactics; improves the resilience of production systems." It is an integration of methods such as physical, cultural, herbal, and biological without any reliance on hazardous chemical pesticides. Chemical pesticides are used as last resort when the population of pest will cross ETL and EIL levels.

b. "Can reduce pesticide use, residues, pest damage, production costs and risks, and health and environmental impacts." It helps to reduce the use of pesticides and thus protects the beneficial insect population along with health of human, livestock, soil, and environment.

c. IPM is a "big tent" of fundamental principles with the strong advantage of flexibility to create new approaches for addressing any pest complex at different levels and thus it adapts to any production goals including the organic production.

\section{High consumption of pesticides in agriculture}

According to the data presented by Pretty and Bharucha [5], global pesticide use has grown over the past 20 years to 3.5 billion $\mathrm{kg} /$ year. Further, they have highlighted the major quantum used in countries of the world. Accordingly, China, USA, and Argentina now account for $70 \%$ of world pesticide use in agriculture (2.44 billion $\mathrm{kg} /$ annum), with China alone now using half of the pesticides worldwide. Six countries each consume between 50 and $100 \mathrm{M} \mathrm{kg}$ (Thailand, Brazil, Italy, France, Canada, and Japan) and thirteen between 10 and $50 \mathrm{M} \mathrm{kg}$ (India, Spain, Germany, Bangladesh, Turkey, South Africa, Russia, Chile, Vietnam, UK, Ghana, Cameroon, and Pakistan). From the data, it can be concluded that India, along with other twelve countries, is ranking third in the consumption.

\section{Economics}

Related to cost of pesticides and pesticide resistance: The external costs of pesticides are \$4-\$19 $(€ 3-15)$ per kg of active ingredient applied [5], indicating the high cost of chemical pesticides, not economical to the farmers in the countries like India.

\section{Demand for organic food}

Rising trend of demand for organic food: Demand for quality-assured products which are chemical free or organic food products.

IPM offers environmental friendly control against pests/vector, provided it is adapted in totality and not only by relying upon the single measure of using hazardous chemical pesticides.

\section{Economic Importance of Vectors and Vector- Borne Diseases of Livestock in Sustainable Agriculture}

Vectors of livestock are having economic significance on three points: (1) Direct losses from their bite and annoyance, (2) diseases they transmit, and (3) expenditure incurred for their control. Flies such as Culicoides spp. and Musca spp. also play important role in disease transmission in addition to their direct effects. 
Tabanus fly-transmitted disease trypanosomosis in buffaloes has a significant impact on the economics of the dairy farmers. Trypanosomosis directly constrains the productivity of cattle by reducing birth rates, increasing abortion rates, and increasing mortality rates [6]. Globally, ticks and tick-borne diseases (TTBDs) are the major constraints on profitable livestock production and productivity. Hemoprotozoan diseases, especially babesiosis, anaplasmosis, theileriosis, and trypanosomosis are considered as the major impediments to the health and productive performance of cattle [7]. Apart from the direct effects, the most important feature of ticks is that they are vectors, as well as reservoirs, of multiple pathogens. Ticks and tick-transmitted parasites have co-evolved with various wild animal hosts, being part of the ecosystem's equilibrium [8]. TBDs, long known but often neglected, are progressively being recognized not only due to their economic impact on livestock but also due to their impact to human health, to which they have become a threat.

Tick-borne diseases cause substantial losses to the livestock industry throughout the world [9] as these have got a serious economic impact due to obvious reason of death, decreased productivity, lowered working efficiency [10], and increased cost for control measures [11]. The TTBDs have been recognized as a major cause of production loss predominantly in tropical and subtropical countries of the world [12-16]. According to the FAO [17], 80\% of the world's cattle population is exposed to tick infestation and has estimated the impact of 7.3 US \$/head/ year. Loss of appetite in heavily tick-infested cattle was found responsible for $65 \%$ of the body weight reduction [18]. The cattle tick Rhipicephalus microplus causes economic losses to the Brazilian cattle industry estimated at U\$3.24 billion per year [19].
Table-1 [20-33] explains how pests of livestock are having economic importance.

\section{Importance of Estimation of Projected Economic Losses}

It is essential for:

a. It is a best approximate estimate of EIL. In implementing IPM practices against the particular pest, a basic monetary benchmark to be taken into account is EIL. The data obtained after calculation of such projected economic losses will be highly useful for work out the losses caused by a single pest and its cost of control.

b. It will help in decision-making about real-time need for control of a pest in a particular geographic area. If losses are less than the cost of control, accordingly decision about control measures to be adapted can be taken.

c. Data generated from such estimations will be of great value to appraise the policy decision makers such as government agencies, NGOs, and private pharmaceutical companies about the research and control programs.

d. In the preamble of many research proposals and in the introductory part of many research articles, to quote the importance of particular parasitic species, it is customary to write huge losses or it is also mentioned that certain million or billion US $\$$ losses per annum. The exact meaning of such huge losses cannot be assessed. Similarly, it is also beyond understanding about how the cited value of million or billion US $\$$ has been assessed. Thus, estimation of projected economic losses will be helpful in citing at least approximate losses occurring on the account of infection of particular parasitic species in question.

Table-1: Effect of vectors-cum-pests on production from livestock resulting in a reduction in economic gains.

\begin{tabular}{|c|c|}
\hline Pest species & Economic losses \\
\hline House flies & $3.3 \%$ decrease in milk production [20] \\
\hline Stable flies & $5 \%$ decrease in milk production $[21]$ \\
\hline Tabanid flies & $\begin{array}{l}0.08-0.10 \mathrm{Kg} \text { loss of weight per day when animal exposed to } 66-90 \text { flies. Decreased } \\
\text { feed efficiency by } 16.9 \%[22]\end{array}$ \\
\hline Culicoides spp. (Biting midges) & $\begin{array}{l}\text { Transmission of bovine ephemeral fever (loss of draught work), BT outbreaks results in } \\
6 \text { million US dollar loss [23] }\end{array}$ \\
\hline Simulium spp.(Black flies) & $\begin{array}{l}\text { Severe morbidity and mortality due to attack by swarms [24], Reduced milk production } \\
\text { and weight gain by } 50 \%[25]\end{array}$ \\
\hline Mosquitoes & $\begin{array}{l}\text { Annual loss in terms of production and control costs amounting to } 5 \text { million US dollar } \\
\text { annually [26] in the USA }\end{array}$ \\
\hline Haematobia irritans (Horn fly) & $\begin{array}{l}\text { Decrease weight gain and milk production [27]. Increased weight in fly free animals } \\
\text { by } 1.06 \mathrm{~kg} / \text { day [28]. In Australia, third most costly disease to cattle producers with } \\
\text { the average loss of production around } \$ 30 \text { per head per year. Total national economic } \\
\text { impact is estimated to be over } \$ 98.7 \text { million a year [29] }\end{array}$ \\
\hline Lice & $\begin{array}{l}\text { In HF calves, weight losses up to } 9.1 \mathrm{~kg}[30] \text {. Total annual losses in American cattle } \\
\text { from lice US } \$ 126.3 \text { million [21] }\end{array}$ \\
\hline Mange mites & Decreased feed conversion efficiency, reduced milk production of $10-15 \%$ \\
\hline Cattle grubs & Reduced milk flow and reduced weight gain. Excessive trimming of hides \\
\hline Ticks & $\begin{array}{l}\$ 275.7 \text { million annual loss [21] Transmission of tick-borne diseases and cost of tick } \\
\text { control. The index in which each engorged female would be responsible for } 8.90 \mathrm{~mL} \\
\text { of milk reduction [31]. Estimated reductions of up to } 50 \% \text { of milk production on dairy } \\
\text { farms were related in the available literature [32] }\end{array}$ \\
\hline B. microplus & Australia US\$ 62 million [33] \\
\hline
\end{tabular}


e. To inform the farmers/milk producers about probable losses, such kind of data are highly useful during extension activities.

f. Similar data can be generated for helminth parasites of livestock for judging the EIL levels for effective implementation of integrated parasite control.

\section{Method of Estimation of Projected Economic Losses}

It shall be first to understand that all these estimates are approximate/projected and exact losses can never be possible to work out. Similarly, it is also to be taken into account that certain yardstick is essential for measuring the probable losses, which can be achieved through estimating the projected economic losses. The factors to be taken into account for estimation are (a) data on total population of a particular geographic area of a particular species of animal, age, sex, milking or non-milking, etc., (b) percent population of a particular animal species affected with the particular pest in a geographic area. Such data can be gathered by retrieving literature about percent prevalence studies undertaken by various research workers, (c) current market rate (CMR) of animal products such as meat/ milk/wool, and (d) total sum of losses from particular pest(direct) or from disease transmission or from $\mathrm{milk} / \mathrm{meat} /$ wool. It can be obtained either from scientific literature available on such parameters or it can be simply worked out by taking into account probable loss and cost of treatment or control. The approximate estimate of losses can be estimated by simple algebraic calculations with following mathematical equation.

$\mathrm{PEL}=\frac{\left[\frac{(\mathrm{TP} \times \mathrm{PPA})}{100} \times \frac{(\mathrm{AP} \times \mathrm{PL})}{100} \times(\mathrm{CMR})\right]}{\mathrm{TP}}$

Where in,

PEL: Projected economic losses from a particular vector/vector-borne disease in a geographical area per animal or from total livestock population.

TP: Total population exposed to vector/at risk in a geographical area.

PPA: Percent population affected/exposed/at risk of vector/vector-borne disease in a geographical area.

AP: Standard average production of milk/meat/wool from individual/from total livestock population animal in a geographical area.

PL: Percentage loss from vector/vector-borne disease an individual animal in terms of milk/meat/wool.

CMR: Current market rate per unit of milk/meat/wool. By taking example cited in Table-2 [20,21,23,26,34-46], above formula can be well explained.

Example 1: (For calculation of projected economic losses for total livestock population).
Total livestock population of total milking cows + buffaloes in India is (TP): 80526070 (8.05 crore) [47].

Percent population affected (PPA) is: $100 \%$.

Standard Average/total milk production of India from total milking cows+buffaloes (AP): 132.43 million tons (13243 core liters) [46].

Percent loss from vector/vector-borne disease to animal in terms of milk (PL):18.97\% [36].

Current market rate per unit of milk (CMR): ₹ 38 .

If these values entered in the above formula, the calculations are...

$\mathrm{PEL}=\frac{\left[\frac{(8.05 \times 100)}{100} \times \frac{(13243 \times 18.97)}{100} \times(38)\right]}{8.05}$

PEL projected economic loss from total cattle and buffalo milking animals population in India per year $=₹ 95463.48$ crore.

Example 2: (For calculation of projected economic losses for individual animal).

Total livestock population of India is (TP): 1 .

Percent population affected (PPA) is: $100 \%$.

Standard average total milk production of India from TP is (AP): $7.02 \mathrm{~L}$ per crossbred cow [46].

Percent loss from vector/vector-borne disease to animal in terms of milk (PL):18.97\% [36].

Current market rate per unit of milk (CMR): ₹ 38 .

If these values entered in the above formula, the calculations are...

PEL $=\frac{\left[\frac{(1 \times 100)}{100} \times \frac{(7.02 \times 18.97)}{100} \times(38)\right]}{1}$

PEL per individual animal $=₹ 50.60$ per crossbred cow per day.

Table-3 [12,39,41,47-52] narrates estimated losses in the literature, while Tables- 4 and 5 [46,47,52-61] exemplify the estimation of approximate projected economic losses by citing the examples of five states.

\section{Recent Developments in IPM}

After 1970, IPM concept in agriculture against crop pests has emerged and flourished to the best possible extent; however, it is at infancy stage against pests of livestock, the reasons could be (a) difficulty in estimating ETL and EIL levels of pest infestation to livestock, (b) very few studies available on mapping of pests in India, (c) poor network of extension activities failed to understand livestock owners about implementation of IPM, and (d) differences in application of IPM tactics from crop pests to livestock pests. Crop pests can be directly attacked on standing crop, while livestock pests have to be attacked simultaneously at their breeding places (off-host) and on animal body (on-host). As a result, IPM against livestock pests appears as difficult 
Table-2: Projected economic losses from important vectors-cum-pests of livestock in India.

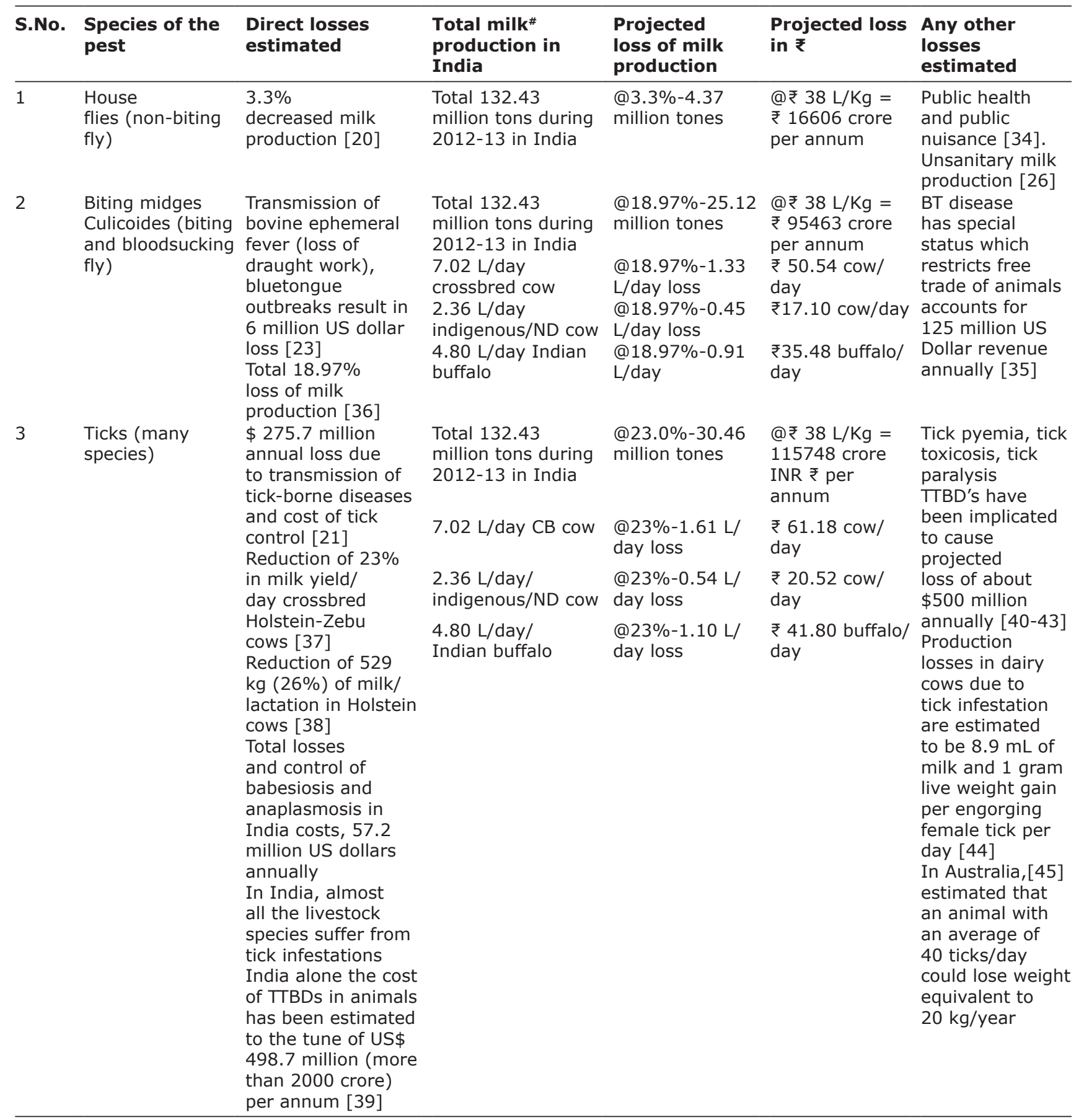

\#Total milk production and average milk production per individual animal are referred from Annual Report 2013-14, Government of India [46]. For calculation of total loss in terms of INR (₹), rate of milk/L is considered as average ₹38/L for buffalo/cow milk

and needs rigorous efforts. However, it has become mandatory to adapt practices of organic farming and IPM in the sustainable agriculture.

Recent trends used for IPM of livestock pests include biological (use of pathogen and predators such as bacterial and fungal agents and herbal pesticides), cultural (provision of good health to animals for resisting the pests), mechanical (grooming combs, flea combs, and electrical devices), physical (sticky fly paper and fly proof net shed), sanitation and habitat modification (cleanliness of stables and animal houses and caulking of cracks and crevices), legal quarantine measures (quarantine of sick and pest infected animals for avoiding the spread of pests), and last resort as use of chemical pesticides. Recently, push-pull mechanism based on semiochemistry has been evolved as emerging trend. In which the use of semiochemicals for control of cattle brown ear tick, use of kairomone trap for control of tsetse flies, and zooprophylaxis using animals for control of malaria transmitted by Anopheles arabiensis mosquitoes are the some of the examples. 
Table-3: Losses due to TTBD reviewed from the literature.

\begin{tabular}{|c|c|c|c|c|c|}
\hline S.No. & $\begin{array}{l}\text { Disease transmitted by } \\
\text { vector }\end{array}$ & Losses & Reference & $\begin{array}{l}\text { Losses as on today in } \\
\text { October } 2017 \$[51]\end{array}$ & $\begin{array}{l}\text { Losses in } ₹ \text { in } \\
\text { October } 2017 * \\
(1 U S \$=₹ 65.07 \text { on } \\
18.10 .2017)\end{array}$ \\
\hline 1 & $\begin{array}{l}\text { In India tropical } \\
\text { theileriosis }\end{array}$ & $\begin{array}{l}\text { Annual loss US\$ } 800 \\
\text { million }\end{array}$ & [48] & US\$1295 million & ₹ 8426.7 crore \\
\hline 2 & $\begin{array}{l}\text { A recent estimate } \\
\text { calculated the costs of } \\
\text { control of TTBDs affecting } \\
\text { Indian livestock as }\end{array}$ & $\begin{array}{l}498.7 \text { million US \$ per } \\
\text { annum }\end{array}$ & {$[41]$} & US\$668.96 million & ₹4353.0 crore \\
\hline 3 & $\begin{array}{l}\text { Total losses due to surra } \\
\text { per animal in ND cow, CB } \\
\text { cow, and buffalo }\end{array}$ & $\begin{array}{l}\text { ND: ₹ 3, 328.18, } \\
\text { CB: ₹ 6, } 193 \text { and } \\
\text { buffalo: ₹9,872.33 }\end{array}$ & [49] & $\begin{array}{l}\text { ND: ₹ } 183.86 \text { crore } \\
\text { CB: ₹ } 713.5 \text { crore } \\
\text { buffaloes: ₹ } 311.21 \\
\text { crore }\end{array}$ & $\begin{array}{l}\text { ND: } ₹ 183.86 \text { crore } \\
\text { CB: ₹ } 713.5 \text { crore } \\
\text { buffaloes: ₹ } 311.21 \\
\text { crore }\end{array}$ \\
\hline 4 & $\begin{array}{l}\text { India suffers losses due } \\
\text { to babesiosis in livestock }\end{array}$ & $\begin{array}{l}57.2 \text { million US dollars } \\
\text { annually }\end{array}$ & {$[50]$} & US\$ 84.74 & $₹ 551.54$ crore \\
\hline 5 & $\begin{array}{l}\text { In India alone, TTBD's } \\
\text { have been implicated to } \\
\text { cause projected loss }\end{array}$ & $\$ 500$ million annually & [39] & US\$ 595.20 & ₹ 3873.06 crore \\
\hline 6 & $\begin{array}{l}\text { As per the } 1997 \\
\text { estimates, the global } \\
\text { production loss caused } \\
\text { by TTBDs }\end{array}$ & $\begin{array}{l}13.9-18.7 \text { billion US } \$ \\
\text { annually }\end{array}$ & {$[12]$} & $\begin{array}{l}21.38-28.76 \text { billion US } \\
\$ \text { annually }\end{array}$ & \\
\hline
\end{tabular}

*https://www.exchange-rates.org/Rate/USD/INR

Table-4: Projected economic losses due to trypanosomosis in buffaloes in India.

\begin{tabular}{|c|c|c|c|c|c|c|c|c|}
\hline \multirow[t]{2}{*}{ S.No. } & \multirow[t]{2}{*}{ State } & \multirow{2}{*}{ Reference } & \multirow{2}{*}{$\begin{array}{c}\% \\
\text { Prevalence } \\
\mathbf{a}\end{array}$} & \multirow{2}{*}{$\begin{array}{c}\text { Total } \\
\text { \#population [47] } \\
\text { b }\end{array}$} & \multirow{2}{*}{$\begin{array}{c}\begin{array}{c}\text { Affected } \\
\text { population }\end{array} \\
\mathbf{a} \times \mathbf{b} / \mathbf{1 0 0}=\mathrm{c}\end{array}$} & \multirow{2}{*}{$\begin{array}{c}\text { Loss of milk } \\
\text { per affected } \\
\text { animal in } \\
₹[49] \\
\text { d }\end{array}$} & \multirow{2}{*}{$\begin{array}{c}\text { Total } \\
\text { loss in ₹ } \\
\mathrm{c} \times \mathrm{d}=\mathrm{e}\end{array}$} & \multirow{2}{*}{$\begin{array}{c}\text { Loss per } \\
\text { animal in ₹ } \\
\text { e/b }\end{array}$} \\
\hline & & & & & & & & \\
\hline 1 & Andhra Pradesh & {$[52]$} & 7.28 & 9272257 & 675020 & 9872.33 & $\begin{array}{c}666.40 \\
\text { crore }\end{array}$ & 718.70 \\
\hline 2 & Chhattisgarh & {$[53]$} & 22.03 & 600463 & 132281 & 9872.33 & $\begin{array}{c}130.59 \\
\text { crore }\end{array}$ & 2174.8 \\
\hline 3 & Karnataka & {$[54]$} & 12.9 & 3110131 & 401206 & 9872.33 & $\begin{array}{c}396.08 \\
\text { crore }\end{array}$ & 1273.5 \\
\hline 4 & Punjab & {$[55]$} & 9.35 & 4626033 & 432534 & 9872.33 & $\begin{array}{c}427.01 \\
\text { crore }\end{array}$ & 923.06 \\
\hline 5 & Overall India & {$[56]$} & 2.69 & 92599075 & 2490915 & 9872.33 & $\begin{array}{c}2459.1 \\
\text { crore }\end{array}$ & 286.2 \\
\hline
\end{tabular}

\#19th Livestock Census [47]

Table-5: Projected economic losses due to theileriosis in CB cattle in five states of India

\begin{tabular}{|c|c|c|c|c|c|c|c|c|c|c|}
\hline \multirow[t]{2}{*}{ S.No. } & \multirow[t]{2}{*}{ State } & \multirow[t]{2}{*}{ Reference } & \multirow{2}{*}{$\begin{array}{c}\% \\
\text { Prevalence } \\
\text { a }\end{array}$} & \multirow{2}{*}{$\begin{array}{c}\begin{array}{c}\text { Total } \\
\text { \#population }\end{array} \\
\text { b }\end{array}$} & \multirow{2}{*}{$\begin{array}{c}\begin{array}{c}\text { Affected } \\
\text { population }\end{array} \\
\mathrm{a} \times \mathrm{b} / \mathbf{1 0 0}=\mathrm{c}\end{array}$} & \multirow{2}{*}{$\begin{array}{c}\begin{array}{c}\text { Loss of } \\
\text { milk [41] }\end{array} \\
\text { d }\end{array}$} & \multirow{2}{*}{$\begin{array}{c}\text { Rate } \\
\text { e }\end{array}$} & \multirow{2}{*}{$\begin{array}{c}\begin{array}{c}\text { Total } \\
\text { loss of } \\
\text { milk }\end{array} \\
\text { cxd = f }\end{array}$} & \multirow{2}{*}{$\begin{array}{c}\text { Total } \\
\text { loss } \\
\text { in ₹ in } \\
\text { crore } \\
\text { exf }=g\end{array}$} & \multirow{2}{*}{$\begin{array}{c}\begin{array}{c}\text { Loss } \\
\text { per } \\
\text { animal } \\
\text { in } ₹\end{array} \\
\mathbf{g} / \mathbf{b}\end{array}$} \\
\hline & & & & & & & & & & \\
\hline 1 & & & 37.0 & & & 127 & 38 & 8148 & 30 & 1785 \\
\hline 2 & Karnataka & & 17.7 & & & 127 & 38 & 60858182 & & \\
\hline 3 & Kerala & {$[5$} & 16.0 & 1115375 & & 127 & 38 & 22664420 & 86.12 & 772.16 \\
\hline 4 & Tamil Nadu & [60] & 13.0 & 5467646 & & 127 & 38 & 90270838 & 343.02 & 627.38 \\
\hline 5 & Uttarakhand & [61] & 45.4 & 416977 & 189307 & 127 & 38 & 24042058 & 91.35 & 2191.00 \\
\hline
\end{tabular}

$\mathrm{d}=$ Loss of milk per affected animal in liter, e=Rate of milk per liter considered as ₹ 38, "19th Livestock Census [47]

To update recent developments in the areas of IPM, IPM practices are exemplified for two representative major vectors of livestock, one representing flies group (Diptera) and another representing Acarina group.

\section{Culicoides midges}

Physical: Provision of Net shed [62,63].

Modeling of midge population and prediction models: More extensive modeling of Culicoides biting midge populations in different geographical contexts will help to optimize control strategies and predictions of disease outbreaks [64-67].

\section{Biological}

a. Metarhizium anisopliae [68,69], Metarhizium is not toxic to mammals and environmentally friendly biological control agent for Culicoides brevitarsis [70]. 
b. Bacillus cereus (CWBI-B1082) [36,71].

c. Bacillus thuringiensis var Israelensis, Bacillus sphaericus, Bacillus weihenstephanensis WSBC, and $B$. weihenstephanensis KBAB4 [72].

d. Predacious guppy fishes: Poecilia reticulata [73].

e. Herbal control with Neem and Karanj oil [74].

f. Animal shelter management [75].

g. Mechanical control through habitat modification [76].

h. Culicoides species becoming less susceptible to deltamethrin thus need of alternative control [77].

i. Integrated management of Culicoides spp. [78].

\section{Rhipicephalus (B.) microplus}

\section{Physical}

Caulking process involving burning of tick eggs in the cattle shed for the annihilation of breeding places to be undertaken 3 consecutive times at weekly interval in a season [79], by slow burning over 1 or 2 days [80].

\section{Biological}

a. Verticillium lecanii and Beauveria bassiana strain LBBb-14 (applied on calves body) [81].

b. In vitro efficacy of $B$. bassiana in engorged females [82].

c. Strain Ma-z4 of M. anisopliae and strain Bb-1 of B. bassiana (applied directly to animal body) [83].

d. Use of three herbal oils: Neem oil (Azadirachta indica), karanj oil (Pongamia pinnata), and Nilgiri oil (Eucalyptus globulus) [36]. Alcoholic extracts of sitaphal (Annona squamosa) and neem (A. indica) against different life stages [39]. Crude extracts of Allium sativum cloves and Carica papaya seeds [84], use of herbal preparations used in ethnoveterinary and as green-fabricated nanoparticles as novel approach [85].

e. Fungal control: M. anisopliae and B. bassiana [86-90]; M. anisopliae and B. bassiana gain high value in biological control of ticks because both the funguses exhibited the strongest anti-tick pathogenicity [91-93].

f. Pheromones used by ticks for aggregation and mating can be artificially used in combination with acaricides [94].

g. Use of oil formulation of funguses: The use of oil formulations containing these entomopathogens may increase the conidia stability and extend their persistence in the field protecting fungi against heat stress, desiccation, and particularly ultraviolet irradiation [95-99].

Tick vaccine

Subolesin as a candidate vaccine antigen for the control of cattle tick infestations in Indian situation [100].

\section{Conclusion}

Vectors and vector-transmitted diseases in livestock pose high economic losses and need to be addressed using recent tool in the form of well-known concept of IPM. To successfully implement the concept of IPM, for each vector species, estimation of two monitory benchmarks, i.e. EIL and ETL is essential prerequisite. Accurate estimation of these two benchmarks appears to be difficult for almost all vector species infecting and transmitting the diseases in livestock. Under such scenario, a method for approximate estimation, first time, described and elaborated in the present review article has immense utility. The method described is based on the consideration of all important key factors such as percent prevalence of vectors in a geographical area, percent losses produced, total livestock population and current prices of livestock products such as milk, meat, and wool, and thus, economic losses estimated are close to the accuracy. Therefore, the method described is recommended for field utility.

\section{Authors' Contribution}

$\mathrm{BWN}$ is the sole author.

\section{Acknowledgments}

The facilities provided by College of Veterinary and Animal Sciences, MAFSU, Parbhani are acknowledged.

\section{Competing Interests}

The author declares that he has no competing interests.

\section{References}

1. Baker, B.P., Cooley, D., Futrell, S., Garling, L., Gershuny, G., Green, T.A., Moyer, J., Rajotte, E.D., Seaman, A.J. and Young, S.L. (2015) Synergistic Partnership Needed to Improve the Sustainability of Agriculture and Food Systems. Organic Agriculture and Integrated Pest Management: A Publication of the National Organic and IPM Working Group. Available from: https://www.organicipmwg.files. wordpress.com $/ 2015 / 07 /$ white-paper.pdf. Accessed on 20-10-2016.

2. Jarvis, L.S. (1988) Strategies for Sustainable Animal Agriculture in Developing Countries. Available from: http:// www.fao.org/docrep/004/t0582e/T0582E06.htm. Accessed on 19-10-2017.

3. Mullens, B.A. (1991) Integrated management of Culicoides variipennis: A problem of applied ecology. In: Walton, T.E. and Osburn, B.I., editor. Blue Tongue, African Horse Sickness and Related Orb viruses. Proceedings of the $2^{\text {nd }}$ International Symposium 17-21 June 1991, Paris, 1992. CRC Press, Boca Raton, Florida, USA, p896-905.

4. USDA ERS. (2013) Organic Production. Data Source. USDA Economic Research Service. October 24. Available from: http://www.ers.usda.gov/data-products/organic-roduction.aspx\#.VDbWc97P6S0. Accessed on 18-10-2017.

5. Pretty, J. and Bharucha, Z.P. (2015) Integrated pest management for sustainable intensification of agriculture in Asia and Africa. Insects, 6(1): 152-182.

6. Mersha, C., Adula, D.D. and Bogale, B. (2013) Socioeconomic assessment of the impacts of trypanosomiasis on cattle in Girja District, Southern Oromia Region, Southern Ethiopia. Acta Parasitol. Glob., 4: 80-85.

7. Rajput, Z.I., Hu, S., Chen, W., Arijo, A.G. and Xiao, C. (2006) Importance of ticks and their chemical and immunological control in livestock. J. Zhejiang Univ Sci. B, 
7: $912-921$.

8. Jongejan, F. and Uilenberg, G. (2004) The global importance of ticks. Parasitology, 129: 1-12.

9. Ananda, K.J., D’Souza, P.E. and Puttalakshmamma, G.C. (2009) Prevalence of haemoprotozoan diseases in crossbred cattle in Bangalore north. Vet. World, 2(1): 15-16.

10. Uilenberg, G. (1995) International collaborative research: Significance of tick-borne hemoparasitic diseases to world animal health. Vet. Parasitol., 57: 19-41.

11. Makala, L.H., Mangani, P., Fujisaki, K. and Nagasawa, H. (2003) The current status of major tick borne diseases in Zambia. Vet. Res., 34: 27-45.

12. De Castro, J.J. (1997) Sustainable tick and tick borne disease control in livestock improvement in developing countries. Vet. Parasitol., 71: 77-97.

13. Parthiban, M., Saranya, R., Mahesh, M. and Raman, M. (2010) Detection of parasite in cattle of Tamil Nadu using nested PCR. Tamil Nadu J. Vet. Anim. Sci., 6: 162-165.

14. Lurthu, R.T., Shibi, T.K. and Babu, M. (2012) Occurrence of haemoprotozoan infection in bovines. Int. J. Appl. Biores., 13: $1-2$.

15. Arunkumar, S. and Nagarajan, K. (2013) A study on prevalence status of infection among cattle population of Kancheepuram and in and around Chennai districts of Tamil Nadu. Int. J. Food Agric. Vet. Sci., 3: 155-157.

16. Mondal, D.B., Sarma, K. and Saravanan, M. (2013) Upcoming of the integrated tick control program of ruminants with special emphasis on livestock farming system in India. Ticks Tick-borne Dis., 4: 1-10.

17. FAO. (2004) Ticks: Acaricide resistance, diagnosis, management and prevention. In: Resistance Management and Integrated Parasite Control in Ruminants: Guidelines Module 1. Animal Production and Health Division, Food and Agriculture Organization of the United Nations, Rome. p25-77.

18. Seebeck, R.M., Springell, P.H. and O'Kelly, J.C. (1971) Alterations in the host metabolism by the specific and anorectic effects of the cattle tick (Boophilus microplus) in food intake and body weight growth. Aust. J. Biol. Sci., 24: $373-380$

19. Grisi, L., Leite, R.C., Martins, J.R.S., Barros, A.T.M., Andreotti, R., Cançado, P.D. and Villela, H.S. (2014) Reassessment of the potential economic impact of cattle parasites in Brazil. Braz. J. Vet. Parasitol., 23: 150-156.

20. Freeborn, S.B., Regan, W.M. and Folger, A.H. (1925) The relation of flies and fly sprays to milk production. J. Econ. Entomol., 18: 779-790.

21. Drummond, R.O.G., Lambart, G., Smalley, H.E. Jr. and Terrill, C.E. (1981) Estimated losses of livestock to pests. In: Pimentel, D., Geden, C.J., Hogsette, J.A., editors. Handbook of Pest Management in Agriculture. Vol. I. CRC Press, Inc., Boca Raton FL, Held at Lincoln, Nebraska. p111-127.

22. Perich, M.J., Wright, R.E. and Lusby, K.S. (1986) Impact of horse flies (Diptera: Tabanidae) on beef cattle. J. Econ. Entomol., 79: 128-131.

23. Metacalf, H.E., Lomm, J. and Beal V.C.Jr. (1980) Estimate of incidence and direct economic losses due to bluetongue in Mississippi cattle during 1979. Proc. Ann. Mtng U.S. Anim. Hlth Assoc., 84: 186-202.

24. Millar, J.L. and Rempel, J.G. (1944) Livestock losses in Saskatchewan due to black flies. Can. J. Comp. Med. Vet. Sci., 8: 334-337.

25. Fredeen, F.J.H. (1956) Black flies (Diptera: Simuliidae) of the agricultural areas of Manitoba, Saskatchewan and Alberta. Proc. 10 $0^{\text {th }}$ Int. Congr. Entomol., 10: 819-823.

26. Anonymous. (1994) In: Geden, C.J. and Hogsette, J.A. editors. Proceedings of Workshop on Research and Extension Needs for Integrated Pest Management for Arthropods of Veterinary Importance. Held at Lincoln, Nebraska. p12-14. Available from: http://www.Cmave.usda.ufl.edu/Lincoln. html. Accessed on 15-07-2007.
27. Bruce, W.N. and Decker, G.C. (1958) The relationship of stable fly abundance to milk production in dairy cattle. $J$. Econ. Entomol., 51: 269-274.

28. Block, E. and Lewis, D.J. (1986) Efficacy of insecticidal ear tags on fly control and milk production of dairy cows. Can. J. Anim. Sci., 66: 47-51.

29. Lane, J., Jubb, T., Shephard, R., Webb-ware, J. and Fordyce, G. (2015) Priority List of Endemic Diseases for the Red Meat Industries. Meat and Livestock Australia (MLA), Sydney, NSW.

30. DeVaney, J.A. Craig, T.M., Rowe, L.D., Wade, C. and Miller, D.K. (1992) Effects of low levels of lice and internal nematodes on weight gain and blood parameters in calves in central Texas. J. Econ. Entomol., 85: 144-149.

31. Jonsson, N.N., Mayer, D.G. and Matschoss, A.L. (1998) Production effects of cattle tick (Boophilus microplus) infestation of high yielding dairy cows. Vet. Parasitol., 78: 65-77.

32. Rodrigues, D.S. and Leite, R.C. (2013) Economic impact of Rhipicephalus (Boophilus) microplus: Estimate of decreased milk production on a dairy farm. Arq. Bras. Med. Vet. Zootec., 65: 1570-1572.

33. Springell, P.H. (1974) The cattle tick in relation to animal production in Australia. World Anim. Rev., 10: 19-23.

34. Miller, R.W. (1993) The influence of dairy operations on the urban fly problem. In: Thomas, G.D., Skoda, S.R., editors. Rural Flies in Urban Environment. University of Nebraska, Lincoln NB. p25-33.

35. Holbrook, F.R. (1988) Bluetongue in the U.S.: Status, transmission and control through vector suppression. Bull. Soc. Vect. Ecol., 13: 350-353.

36. Narladkar, B.W. and Shivpuje, P.R. (2012) Research Project Report of Development of Integrated Pest Management Module Against Important Dipteran Pests of Livestock with Reference to Culicoides Midges (Diptera: Ceratopogonidae) Financed and Accepted by Department of Biotechnology, Government of India, New Delhi. p1-167.

37. Furlong, J., Derez, F., Matos, L.L. and Balbi, M.V. (1996) The Effect of Cattle Tick Boophilus microplus (Acari: Ixodidae) Infestation on Feed Intake and Milk Yield of Holstein x Zebu Zebu Crossbred Cows. Proceeding XV Pan-American Congress Vet, Campo Grande. p340.

38. Teodoro, R.L., Lemos, A.M. and Madalena, F.E. (1998) Effects of ticks Boophilus microplus infestations on milk yield of Bostaurus/Bosindicus crosses. Proceeding of the $6^{\text {th }}$ World Congress Genetics. Applied to livestock Production, Amidala, Australia. p137-180.

39. Ghosh, S., Azhahianambi, P. and Yadav, M.P. (2007) Upcoming and future strategies of tick control: A review. $J$. Vector Dis., 44: 79-89.

40. Geevarghese, G., Fernandes, S. and Kulkarni, S.M. (1997) A checklist of Indian ticks (Acari: Ixodoidea). Indian J. Anim. Sci., 67: 566-574.

41. Minjauw, B. and McLeod, A. (2003) Tick-borne diseases and poverty. The impact of ticks and tick borne diseases on the livelihood of small-scale and marginal livestock owners in India and eastern and southern Africa. Research Report, DFID Animal Health Programme, Centre for Tropical Veterinary Medicine, University of Edinburgh, UK. Available from: http://www.r4d.dfid.gov.uk/PDF/Outputs/ RLAHTickBornBook.pdf.(Last Accessed on 18.09.2017)

42. Ghosh, S., Bansal, G.C., Gupta, S.C., Ray, D., Khan, M.Q., Irshad, H., Shahiduzzaman, M.D., Seitzer, U. and Ahmed, J.S. (2007) Status of tick distribution in Bangladesh, India and Pakistan. Parasitol. Res., 101 Suppl 2: 207-216.

43. Chhillar, S., Chhilar, J.S. and Harpreet, K. (2014) Investigations on some hard ticks (Acari: Ixodidae) Infesting domestic buffalo and cattle from Haryana, India. J. Entomol. Zool. Stud., 2: 99-104.

44. Jonsson, N.N., Davis, R. and De Witt, M. (2001) 'An estimate of the economic effects of cattle tick (Boophilus microplus) infestation on Queensland dairy farms'. Aust. Vet. J., 79: 826-831. 
45. Frisch, J.E., O’Neill, C.J. and Kelly, M.J. (2000) Using genetics to control cattle parasites - The rock hampt on experience. Int. J. Parasitol., 30: 253-264.

46. Annual Report. (2013-14) Department of Animal Husbandry, Dairying and fisheries. Ministry of Agriculture, Government of India, New Delhi. Available from: http:// www.dahd.nic.in. Accessed on 19-10-2017.

47. $19^{\text {th }}$ Livestock Census. (2012) All India Report, Ministry of Agriculture, Department of Animal Husbandary, Dairying and Fisheries, Krishi Bhavan New Delhi, Government of India.

48. Devendra, C. (1995) In Global Agenda for Livestock Research. EDS, ILRI, Nairobi. p41-48.

49. Singh, D., Kumar, S., Singh, B. and Bardhan, D. (2014) Economic losses due to important diseases of bovines in central India. Vet. World, 7(8): 579-585.

50. McLeod, R. and Kristjanson, P. (1999) Tick Cost: Economic Impact of Ticks and TBD to Livestock in Africa, Asia and Australia. International Livestock Research Institute (ILRI), Nairobi, Kenya. Available from: http://www.esys.com.au; http://www.cgiar.org/ilri. Accessed on 10-08-2016.

51. US Inflatation Calculator. Available from: http://www.usinflationcalculator.com. Accessed 18-10-2017.

52. Bhaskara, R.T. and Hafeez, M.D. (2005) Prevalence of trypanosomiasis in buffaloes in East Godavari district of Andhra Pradesh. Indian Vet. J., 82: 896-897.

53. Roy, S., Tiwari, A., Galdhar, C.N., Upadhyay, S.R., Ratre, H.K., Sahu, S.K. and Maiti, S.K. (2004) Seasonal prevalence of haemoprotozoan diseases in cross-bred cattle and buffaloes. Indian J. Vet. Med., 24: 5-7.

54. Krishnappa, T., Muralidhara, A., Sastry, K.N.V., Renuprasad, C. and Krishnappa, G. (2002) Prevalence of trypanosomiasis in domestic animals in Karnataka. Indian Vet. J., 79: 183-184.

55. Rani, N.L., Suresh, K. and Rajesh, K. (2015) A retrospective study on clinico-epidemiological aspects of trypanosomiasis in buffaloes. Int. J. Vet. Sci., 4: 97-100.

56. Laha, R., Prasad, K.D. and Saral, B.N. (1989) Incidence of Trypanosoma evansi infection in cattle, buffaloes and goats in and around Ranchi. Bihar J. Res. Birsa Agri. Univ., 1: 111-112.

57. Vahora, S.P., Patel, J.V., Patel, B.B., Patel, S.B. and Umale, R.H. (2012) Seasonal incidence of haemoprotozoan diseases in the areas where the chances of occurrence of such crossbred cattle and buffalo in Kaira and Anand district of disease is very low. Gujarat, India. Vet. World, 5: 223-225.

58. Muraleedharan, K., Ziauddin, K.S., Hussain, P.M., Seshadri, S.J., Mallika, A.G.B. and Puttabyatappa, B. (1994) Observations on theilerial infection of cattle in project area of Mysore cooperative milk producer's union, Karnataka state. Cheiron, 23: 130-139.

59. Nair, A.S., Ravindran, R., Lakshmanan, B., Kumar, S.S., Tresamol, P.V., Saseendranath, M.R., Senthilvel, K., Rao, J.R., Tewari, A.K. and Ghosh, S. (2011) Haemoprotozoan of cattle in Northern Kerala, India. Trop. Biomed., 28: 68-75.

60. Velusamy, R., Rani, N., Ponnudurai, G., Harikrishnan, T.J., Anna, T., Arunachalam, K., Senthilvel, K. and Anbarasi, P. (2014) Influence of season, age and breed on prevalence of haemoprotozoan diseases in cattle of Tamil Nadu, India. Vet. World, 7: 574-578.

61. Kohli, S., Atheya, U.K. and Thapliyal, A. (2014) Prevalence of theileriosis in cross-bred cattle: Its detection through blood smear examination and polymerase chain reaction in Dehradun district, Uttarakhand, India. Vet. World, 7: $168-171$.

62. Calvete, C., Estrada, R., Miranda, M.A., Del Rio, R., Borrás, D., Beldron, F.J., Martínez, A., Calvo, A.J. and Lucientes, J. (2010) Protection of livestock against bluetongue virus vector Culicoides imicola using insecticide-treated netting in open areas. Med. Vet. Entomol., 24: 169-175.

63. Narladkar, B.W. and Shivpuje, P.R. (2014) Fly proof net shed for livestock: A novel concept of physical barrier for integrated management of Culicoides spp (Diptera: Ceratopogonidae). Vet. World, 7: 899-908.

64. Narladkar, B.W., Deshpande, P.D., Shivpuje, P.R. and Sondge, V.D. (2006) Population dynamics of Culicoides sp of domesticated animals of Marathwada region. J. Vet. Parasitol., 20: 171-174.

65. O'Farrell, H. and Gourley, S.A. (2014) Modeling the dynamics of bluetongue disease and the effect of seasonality. B. Math. Biol., 76: 1981-2009.

66. Nayduch, D., Cohnstaedt, L.W., Saski, C., Lawson, D., Kersey, P. and Fife, M. (2014) Studying Culicoides vectors of BTV in the post-genomic era: Resources, bottlenecks to progress and future directions. Virus Res., 182: 43-49.

67. White, S.M., Christopher, J., Sanders, C.J., Christopher, R., Shortall, C.R., Bethan, V. and Purse, B.V. (2017) Mechanistic model for predicting the seasonal abundance of Culicoides biting midges and the impacts of insecticide control. Parasit. Vector, 10: 162.

68. Ansari, M.A., Pope, E.C., Carpenter, S., Scholte, E.J. and Butt, T.M. (2011) Entomopathogenic fungus as a biological control for an important vector of livestock disease: The Culicoides biting midge. PLoS One, 6(1): e16108.

69. Narladkar, B.W., Shivpuje, P.R. and Harke, P.C. (2015a) Fungal agents for biological control of Culicoides spp (Diptera: Ceratopogonidae) of livestock. Vet. World, 8: $156-163$.

70. Nicholas, A.H. and McCorkell, B. (2014) Evaluation of Metarhizium anisopliae for the control of Culicoides brevitarsis Kieffer (Diptera: Ceratopogonidae), the principal vector of bluetongue virus in Australia. J. Vector Ecol., 39: 213-218.

71. Dylko, N.I. (1979) Biological control of blood sucking flies. Vet. Bull. Abstr. 50: 4966.

72. Narladkar, B.W., Shivpuje, P.R. and Harke, P.C. (2015b) Bacterial agents for biological control of Culicoides spp (Diptera: Ceratopogonidae). Indian Vet. J., 92: 24-28.

73. Narladkar, B.W. (2003) Studies on Bio-Ecological Aspects, Vector Potentiality and Integrated Management of Culicoides spp (Diptera: Ceratopogonidae) of Marathwada region. Ph.D. Thesis approved by Maharashtra Animal and Fishery Sciences University Nagpur, Maharashtra State.

74. Narladkar, B.W. and Shivpuje, P.R. (2015c) Herbal agents for biological control of Culicoides spp (Diptera: Ceratopogonidae). Indian Vet J., 92(5): 20-23.

75. Bandeira, M.D.C.A, Brito, G.A., da Penha, A. and Rebêlo, J.M.M. (2017) The influence of environmental management and animal shelters in vector control of Culicoides (Diptera, Ceratopogonidae) in northeastern Brazil. J. Vector Ecol., 42: 113-119.

76. Harrup, L.E., Miguel, A., Miranda, M.A. and Carpenter, S. (2016) Advances in control techniques for Culicoides and future prospects. Vet. Ital., 52: 247-264.

77. De Keyser, R., Cassidy, C., Laban, S., Gopal, P., Pickett, J.A., Reddy, Y.K., Prasad, M., Prasad, G., Sreekumar, C., Senthilven, K., Carpenter, S. and Logan, J.G. (2017) Insecticidal effects of deltamethrin in laboratory and field populations of Culicoides species: How effective are host contact reduction methods in India? Parasite. Vectors, 10: 54 .

78. Narladkar, B.W., Deshpande, P.D., Vadlamudi, V.P., Shivpuje, P.R. and Deshpande, A.R. (2006) Integrated management of Culicoides sp of domesticated animals. J. Vet. Parasitol., 20: 125-128.

79. Narladkar, B.W. and Shivpuje, P.R. (2015d) Integrated approach for Rhipicephalus microplus tick management through physical measures and herbal bio-control agents. Indian Vet. J., 92: 29-33.

80. Muhammad, G., Naureen, S., Firyali, S. and Saqib, M. (2008) Tick control strategies in dairy production medicine. Pak. Vet. J., 28: 43-50.

81. Rijo, E. (1998) Biological control of ticks with entomopathogenic fungi. Riv. Pecuaria Nicaragua, 22: 17-18. 
82. Bittencourt, V., Souza, E.J., Peralva, S. and Mascarenhas, A. (1997) Evaluation of the in vitro efficacy of two isolates of the entomopathogenic fungus Beauveria bassiana (Bals.) vuill. in engorged females of Boophilus microplus (Canestrini, 1887) (Acari: Ixodidae). Rev. Bras. Parasitol. Vet., 6: 49-52.

83. Lopez, G., Marin, H., Londono, M. and Vahos, R. (1998) Utilization of Metarhizium anisopliae and Beauveria bassiana for the biological control of the tick Boophilus microplus. Noticampo, 10: 12-14.

84. Shyma, K.P., Gupta, J.P., Ghosh, S., Patel, K.K. and Singh, V. (2014) Acaricidal effect of herbal extracts against cattle tick Rhipicephalus (Boophilus) microplus using in vitro studies. Parasitol. Res., 113: 1919-1926.

85. Balan, B., Baskaralingam, V., Periyannan, R., Narayanan, M.P., Palaniappan, R., Kadarkarai, M., Angelo, C. and Giovanni, B. (2017) Exploitation of chemical, herbal and nanoformulatedacaricides to control the cattle tick, Rhipicephalus (Boophilus) microplus - A review. Vet. Parasitol., 244: 102-110.

86. Narladkar, B.W., Shivpuje, P.R. and Harke, P.C. (2015e) Fungal bio-control agents for integrated management of Rhipicephalus microplus ticks. Indian Vet. J., 92: 34-37.

87. Samish, M., Ginsberg, H. and Glazer, I. (2004) Biological control of ticks. Parasitology, 129(S): 389-403.

88. Ren, Q.Y., Liu, Z.J., Guan, G.Q., Sun, M., Ma, M.L., Niu, Q.L., Li, Y.Q., Liu, A.H., Liu, J.L., Yang, J.F., Yin, H. and Luo, J.X. (2012) Laboratory evaluation of virulence of Chinese Beauveria bassiana and Metarhizium anisopliae isolates to engorged female Rhipicephalus (Boophilus) microplus ticks. Biol. Control, 63: 98-101.

89. Sun, M., Ren, Q.Y., Guan, G.Q., Li, Y.F., Han, X.Q., Ma, C., Yin, H. and Luo, J.X. (2013) Effectiveness of Beauveria bassiana sensulato strains for biological control against Rhipicephalus (Boophilus) microplus (Acari: Ixodidae) in China. Parasitol Int., 62: 412-415.

90. Fernanedz-salas, A., Alonoso-diaz, M.A., Alonoso-morale, R.A., Lezama-gutierrez, R., Rodriguez-rodroguez, J.C. and Cervantes-chavez, J.A. (2017) Acaricidal activity of Metarhiziu manisopliae isolated from paddocks in the Mexican tropics against two populations of the cattle tick Rhipicephalus microplus. Med. Vet. Entomol., 31: 36-43.
91. Gindin, G., Samish, M., Alekseev, E. and Glazer, I. (2001) The susceptibility of Boophilus annulatus (Ixodidae) ticks to entomopathogenic fungi. Biocontrol Sci. Tech., 11: 111-118.

92. Samish, M., Gindin, G., Alekseev, E. and Glazer, I. (2001) Pathogenicity of entomopathogenic fungi to different developmental stages of Rhipicephalus sanguineus. J. Parasitol., 87: 1355-1359.

93. Kaaya, G.P. and Hassan, S. (2000) Entomogenous fungi as promising biopesticides for tick control. Exp. Appl. Acarol., 24: 913-926.

94. Sonenshine, D.E. (1993) Biology of Ticks. Vol. II. Oxford University Press, New York. p465.

95. Perinotto, W.M.S., Angelo, C.I., Golo, P.C., Camargo, M.G., Quinelato, S., Sá, F.A., Caio, J.B., Coutinho, R.C.J.B., Marciano, A.F., Monteiro, C.M.O. and Bittencourt, V.R.E.P. (2017) In vitro pathogenicity of different Metarhizium anisopliaes.1. isolates in oil formulations against Rhipicephalus microplus. Biocontrol Sci. Tech., 27: 338-347.

96. Barreto, L.P., Luz, C., Mascarin, G.M., Roberts, D.W., Arruda, W. and Fernandes, E.K.K. (2016) Effect of heat stress and oil formulation on conidial germination of Metarhiziu manisopliaes.s. on tick cuticle and artificial medium. J. Invertebr. Pathol., 138: 94-103.

97. Camargo, M.G., Golo, P.S., Angelo, I.C., Perinotto, W.M.S., Sa, F.A., Quinelato, S. and Bittencourt, V.R.E.P. (2012) Effect of oil-based formulations of acaripathogenic fungi to control Rhipicephalus microplus ticks under laboratory conditions. Vet. Parasitol., 188: 140-147.

98. Camargo, M.G., Marciano, A.F., Sá, F.A., Perinotto, W.M.S., Quinelato, S., Golo, P.S. and Bittencourt, V.R.E.P. (2014) Commercial formulation of Metarhiziu manisopliae for the control of Rhipicephalus microplus in a pen study. Vet. Parasitol., 205: 271-276.

99. Camargo, M.G., Nogueira, M.R., Marciano, A.F., Perinotto, W.M.S., Coutinho-Rodrigues, C.J.B., Scott, F.B. and Bittencourt, V.R.E.P. (2016) Metarhiziu manisopliae for controlling Rhipicephalus microplus ticks under field conditions. Vet. Parasitol., 223: 38-42.

100. Shakya, M., Kumar, B., Nagar, G., de la Fuente, J. and Ghosh, S. (2014) Subolesin: A candidate vaccine antigen for the control of cattle tick in festations in Indian situation. Vaccine, 32: 3488-3494. 